\title{
Declining fertility in the lethal yellow mouse is related to progressive hyperleptinemia and leptin resistance
}

\author{
John D. BRANNIAN ${ }^{a *}$, Gina M. FuRMAN ${ }^{b}$, Maureen DigGins ${ }^{b}$ \\ ${ }^{\text {a }}$ Department of Obstetrics and Gynecology, University of South Dakota, \\ School of Medicine Sioux Falls, SD, USA \\ b Department of Biology, Augustana College, Sioux Falls, SD, USA
}

(Received 26 October 2004; accepted 6 December 2004)

\begin{abstract}
Mice possessing the lethal yellow mutation (C57BL/6J A $\mathrm{y} / \mathrm{a}$ ) become obese and develop hyperleptinemia and leptin resistance as they age. To determine the relationship between altered leptin physiology and reproductive function in these mice, we compared body weight (BW), serum leptin concentration, ovulation rate, and in vitro blastocyst development among 120- and 180-d-old lethal yellow and black non-mutant (a/a) mice. Estrous female yellow and black mice were mated with fertile black males. Oviducts were flushed $\sim 36 \mathrm{~h}$ after mating and the recovered embryos were cultured for $96 \mathrm{~h}$. BW, serum leptin levels, and the leptin:BW ratio differed among groups as follows: 180 -d yellow $>120$-d yellow $>180$-d black $=120$-d black. Ovulation rate was similar among 120-d yellow and black, and 180-d black mice. Among 180-d yellow mice, five of twelve mice failed to ovulate, but the other seven mice ovulated a similar number of oocytes as their black counterparts $(8.4 \pm 0.9$ versus $8.0 \pm 1.3)$. Non-ovulators had higher $(P<0.05)$ leptin levels $\left(56.6 \pm 1.8 \mathrm{ng} \cdot \mathrm{mL}^{-1}\right)$ than ovulators $(46.2 \pm 3.5)$, but BW did not differ significantly. Fewer embryos from 180-d yellow mice reached the blastocyst stage in culture than did the embryos from black mice (55\% versus $83 \%$, $P<0.05)$. Moreover, blastocyst development in 180-d old yellow mice negatively correlated with leptin levels $(r=-0.797, P=0.032)$ and leptin:BW ratio $(r=-0.847, P=0.016)$, but not with BW. Declining reproductive function in lethal yellow mice appears to be related to increasing levels of leptin and progression of leptin resistance.
\end{abstract}

obesity / leptin / agouti / reproduction

\section{INTRODUCTION}

Leptin is an adipokine whose levels in the circulation are a direct function of body fat mass. Obesity is therefore associated with chronic hyperleptinemia, which can lead to the development of central and/or peripheral leptin resistance [1-3]. Leptin impacts reproduction through a variety of regula- tory mechanisms that include the onset of puberty, control of gonadotropin secretion, gonadal function, implantation, and pregnancy. In the ovary, leptin receptor mRNA and protein are expressed in granulosa, theca, luteal, and microvascular endothelial cells [4-7], as well as oocytes [7, 8]. Leptin receptors are also present in early cleavagestage embryos and blastocysts [9].

* Corresponding author: jbrannia@usd.edu 
That leptin is obligatory for reproduction is demonstrated by the complete infertility of the leptin-deficient $(o b / o b)$ mouse, which is reversible by exogenous leptin administration [10]. A threshold level of leptin is essential for pituitary gonadotropin secretion via the control of hypothalamic GnRH release [11, 12]. However, high levels of circulating leptin, such as those experienced by obese women, are associated with poor fertility $[13,14]$. For example, in our study of 140 first attempted in vitro fertilization (IVF) cycles, pregnancy success, implantation rate, and embryo quality were negatively correlated with serum leptin concentrations but not with body mass index (BMI) [14]. Moreover, the leptin:BMI ratio, a putative index of leptin resistance, correlated more strongly than did leptin concentration alone [14]. Therefore we hypothesized that leptin resistance resulting from chronic hyperleptinemia may contribute to the diminished fertility commonly associated with obesity. In order to test this hypothesis we sought a suitable animal model.

The lethal yellow (LY) mouse possesses a gene deletion in the promoter and first exon region of the agouti protein gene locus [15]. In rodents, the agouti protein is normally only expressed in skin cells where it is a primary determinant of coat color. The LY deletion brings an upstream promoter into place, resulting in the inappropriate constitutive expression of the agouti gene in essentially all tissues [15]. This mutant allele is designated $\mathrm{A}^{\mathrm{y}}$. The homozygotes $\left(\mathrm{A}^{\mathrm{y}} / \mathrm{A}^{\mathrm{y}}\right)$ undergo embryonic death, hence the "lethal" designation. Heterozygous mice $\left(\mathrm{A}^{\mathrm{y} / \mathrm{a})}\right.$ are viable, but exhibit distinct characteristics including yellow coat color and adult-onset obesity. The obesity is primarily the result of the agouti protein being over-expressed in the hypothalamus where it interacts with melanocortin-4 receptors (MCR-4) [16]. A structurally-related hypothalamic neurotransmitter, agouti-related protein (AgRP), is a natural antagonist of MCR-4, and via this mechanism plays a critical role in central appetite and metabolism regulation [17]. Therefore the inappropriate over-expres- sion of the agouti protein in the hypothalamus interferes with normal metabolic control causing hyperphagia and altered lipid metabolism [18]. As a consequence of the obesity, these animals progressively develop insulin resistance [19], hyperleptinemia [20], and central leptin resistance [21]. Moreover, lethal yellow mice display accelerated reproductive senescence, which is obesityrelated [22].

Although impaired fertility is a signature feature of the $\mathrm{A}^{\mathrm{y}} / \mathrm{a}$ genotype, reproductive function in these mice has not been well characterized. The purpose of the present study was to further elucidate the premature decline in fertility in the LY mouse, and to determine whether the loss of fertility is related to progressive hyperleptinemia and resultant leptin resistance. If so, the LY mouse might provide a useful model for studying the relationships among hyperleptinemia, leptin resistance and impaired fertility.

\section{MATERIALS AND METHODS}

\subsection{Animals}

All studies were approved by the Institutional Animal Care Committee, Augustana College. Black (BL; C57BL/6J a/a) and LY (C57BL/6 $\mathrm{A} / \mathrm{a}$ ) mice from the Augustana College Biology Department breeding colony were used for the study. Founder mice for this colony were obtained from the Jackson Laboratory (Bar Harbor, ME, USA). All mice were maintained on a 14:10 light/dark cycle with lights on at 0600, and provided with breeder diet (Harlan Teklad, Madison, WI, USA) and fresh water ad libitum.

\subsection{Experimental design}

LY and BL females of the designated ages were placed with BL male mice of proven fertility for up to one week, and allowed to mate naturally when the females were receptive (i.e. estrous). Females were checked each 
morning between 0800 and 0900 for the presence of a vaginal plug indicating that mating had occurred the previous evening. When a plug was observed, the female was removed and placed in a separate cage. Twenty-four hours later, mated females were killed by cervical dislocation, weighed, and trunk blood was collected from the aorta. The oviducts were immediately removed, placed in a sterile glass Petri dish, and flushed using a $27 \mathrm{~g}$ needle attached to a $1 \mathrm{cc}$ tuberculin syringe containing sterile HEPESbuffered saline $+0.1 \%$ BSA. Oocytes and one- and two-cell embryos were recovered and counted. The number of oocytes/embryos recovered was recorded as the ovulation number.

All recovered 1- and 2-cell embryos were cultured in IVC-2 medium (InVitroCare, San Diego, CA, USA) supplemented with $10 \%$ Synthetic Serum Substitute (SSS; Irvine Scientific, Irvine, CA, USA) in an atmosphere of $5 \% \mathrm{CO}_{2} / 95 \%$ air for $96 \mathrm{~h}$. The number of embryos reaching full blastocyst development by $96 \mathrm{~h}$ was recorded and expressed as a percentage of the total number of cleaving embryos (i.e. those that were $\geq 2$-cell at $24 \mathrm{~h}$ in culture) for each mouse. Those that did not cleave were presumed to be unfertilized.

Sera from blood collected at the time of sacrifice were stored at $-20^{\circ} \mathrm{C}$ until assayed for leptin using a homologous RIA kit (Linco Research, St. Louis, MO, USA). For BL mice, $100 \mu \mathrm{L}$ of serum was assayed. Sera from LY mice required a 1:1 dilution because of the higher leptin concentrations. Intra-assay $\mathrm{CV}$ were $<5 \%$ and inter-assay $\mathrm{CV}$ was less than $<15 \%$. As an estimate of relative leptin resistance, serum leptin concentration:body weight (BW) ratio was used as analogous to the leptin:BMI ratio used in human studies.

\subsection{Statistics}

$\mathrm{BW}$, leptin, leptin:BW ratio, and ovulation rate data were analyzed by ANOVA followed by the Duncan multiple range post-hoc test. Blastocyst development was analyzed by Chi-square, and Pearson product moment correlations were used to relate blastocyst development with BW, leptin, and leptin:BW ratio. Significance was conferred at $P<0.05$ for all tests.

\section{RESULTS}

Body weight (BW), serum leptin concentration, and the leptin:BW ratio were greater in 120-d old LY mice than in agematched BL mice (Fig. 1). BW, leptin, and leptin:BW ratio further increased in $\mathrm{LY}$ mice, but not in BL mice, at 180 ds of age. Mean serum leptin concentration was nearly 8 -fold higher in 180-d old LY mice than in their BL counterparts (Fig. 1B).

Ovulation rate did not differ among 120-d old BL and LY mice (Fig. 2). Ovulation rate in 180-d old BL mice was similar to that in 120-d old mice (Fig. 2). Among 180-d old LY mice, five of twelve mice failed to ovulate at all. But the other seven mice ovulated an equivalent number of oocytes as the $\mathrm{BL}$ and younger LY mice (Fig. 2). Gross morphological examination of the ovaries of the mice that did not ovulate revealed a complete absence of preovulatory follicles, recent ovulation sites, or active corpora lutea. Aged LY mice that failed to ovulate were slightly larger, had nearly 2-fold greater serum leptin levels, and had significantly higher leptin: BW ratios than those that ovulated (Fig. 3).

The percentage of embryos recovered from 120-d old LY mice developing to the blastocyst stage tended $(P<0.10)$ to be diminished relative to those from BL mice (Fig. 4). In 180-d old mice, embryos from LY females produced significantly fewer blastocysts than those from BL mice (Fig. 4). Blastocyst development in individual 180-d old LY mice correlated negatively with serum leptin concentration and leptin:BW ratio, but did not correlate with BW (Fig. 5). Moreover, the correlation between blastocyst development and leptin:BW ratio $(r=$ $-0.847, P=0.016$ ) was slightly stronger than 

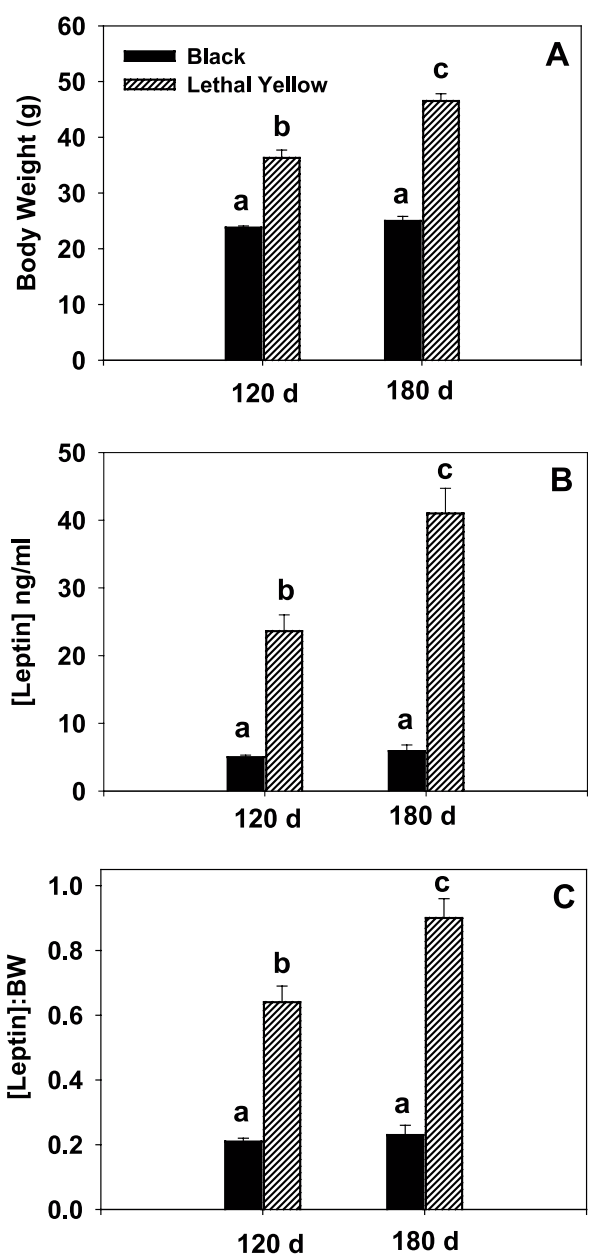

Figure 1. Body weight, g (A), serum leptin concentration, ng.mL $\mathrm{mL}^{-1}(\mathbf{B})$, and leptin:BW ratio (C) of 120- and 180-d old black (solid bars) and lethal yellow (hatched bars) mice (means $\pm \mathrm{SE}, n \geq 8$ per group). Different letters denote differences $(P<0.05)$ among groups by ANOVA and the Duncan test.

with leptin concentration alone $(r=-0.797$, $P=0.032$ ). Blastocyst development did not correlate with $\mathrm{BW}$, leptin concentration, or leptin:BW ratio among BL mice or 120 -d old LY mice.

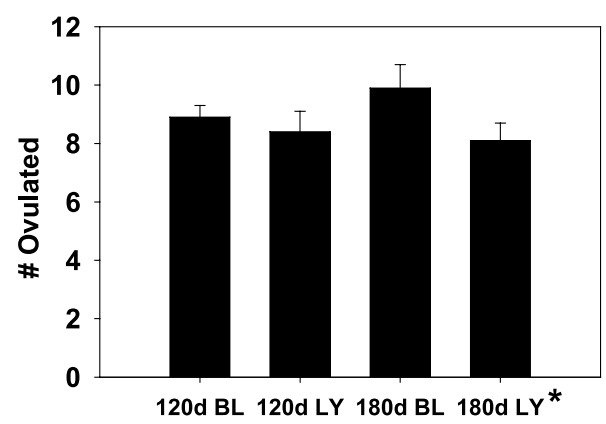

Figure 2. Number of oocytes/embryos recovered from oviducts of 120- and 180-d old black and lethal yellow mice (means \pm SE, $n \geq$ 8 per group). Female mice were mated with fertile black male mice. Oocytes/embryos were recovered $\sim 36 \mathrm{~h}$ after mating. There was no difference in ovulation number among groups. * This does not include five mice that did not ovulate (see text).

\section{DISCUSSION}

This is the first study that relates early reproductive senescence in the obese LY mouse to leptin physiology. The results demonstrate a strong relationship between the loss of reproductive function and increasing circulating leptin concentrations associated with progressive obesity. Moreover, the data suggest that the development of central, and possibly ovarian, leptin resistance may be of key importance to the reproductive decline.

It has been suggested that leptin exerts a generally suppressive effect on ovarian function based on in vitro studies showing leptin inhibition of ovarian steroid synthesis [23-25] and a negative correlation between high leptin levels and fertility in humans $[13,14]$. However, this view seems counterintuitive. Leptin is obligatory for normal reproductive function at the neuroendocrine level, and the high level of leptin receptor expression in the ovaries predicts that leptin should have some complementary direct supportive role in ovarian function. Therefore, we hypothesized that the 


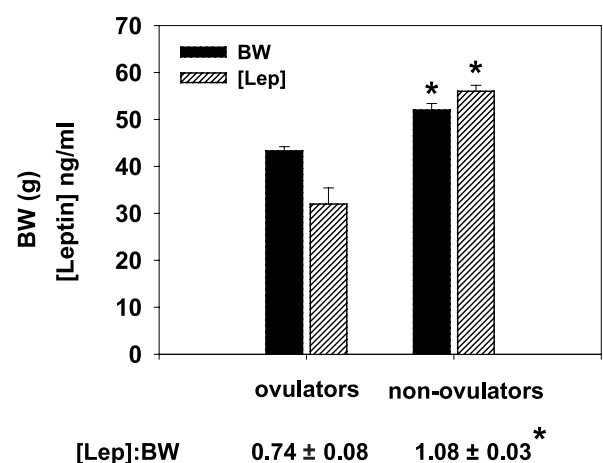

Figure 3. Body weight (g, solid bars) and serum leptin concentration $\left(\mathrm{ng} \cdot \mathrm{mL}^{-1}\right.$, hatched bars) of 180-d old ovulating $(n=7)$ and nonovulating $(n=5)$ lethal yellow mice (means \pm $\mathrm{SE}$ ). Leptin:BW ratio (means $\pm \mathrm{SE}$ ) is shown below the $\mathrm{x}$-axis. Asterisks denote differences $(P<0.05)$ between ovulators and nonovulators by ANOVA and the Duncan test.

relationship between elevated leptin levels and diminished fertility was due to leptin resistance. By analogy, insulin and IGF play important roles in normal ovarian function, yet hyperinsulinemia and insulin resistance, e.g. as occurs in the polycystic ovary syndrome, have a negative impact on follicular dynamics and fertility [26].

Leptin receptor mRNA and protein is expressed in mouse oocytes [7,8] and leptin induces tyrosine phosphorylation of STAT3, a major intracellular leptin signal transduction protein, in mouse metaphase 2 stage oocytes [8]. Ryan and co-workers [7] reported that leptin enhances resumption of meiosis in preovulatory follicle-enclosed oocytes in culture, but does not alter meiotic resumption in denuded or cumulus-enclosed oocytes. Leptin receptor is expressed in mouse 1-cell and 2-cell embryos as well as morulae and blastocysts [9]. These authors demonstrated that the addition of leptin to culture medium promotes blastocyst formation from twocell embryos, and that this effect is neutralized by an antibody directed against the extracellular domain of the leptin receptor. Moreover, leptin increases the total cell

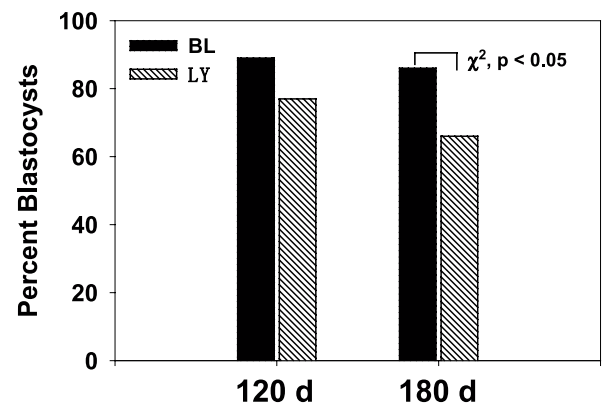

Figure 4. Blastocyst development in vitro (expressed as percent) of embryos from 120and 180-d old black (solid bars) and lethal yellow mice (hatched bars). Embryos were recovered $\sim 36 \mathrm{~h}$ after mating and cultured for $96 \mathrm{~h}$. Of all embryos that cleaved by $24 \mathrm{~h}$ in culture, a lesser percentage $\left(\chi^{2}, P<0.05\right)$ of embryos from 180-d old lethal yellow mice reached the blastocyst stage than embryos from the other groups.

number of the blastocysts formed, and specifically the number of trophectoderm cells [9].

Preliminary studies in our laboratory confirmed the likelihood that leptin supports ovarian function. Twice daily injections of $75 \mu \mathrm{g}\left(\sim 5 \mu \mathrm{g} \cdot \mathrm{g} \mathrm{BW}^{-1}\right)$ recombinant mouse leptin were given to $\mathrm{eCG} / \mathrm{hCG}$-stimulated 28-d old BL mice. Leptin treatment significantly increased total ovulation rate and the number of 2-cell embryos recovered $36 \mathrm{~h}$ after mating (unpublished data).

Systemic injection of leptin into a/a (BL) and $o b / o b$ mice led to marked weight loss, whereas the same treatment resulted in no reduction in weight in $\mathrm{A}^{\mathrm{y}} / \mathrm{a}$ mice [27] demonstrating their hypothalamic resistance to leptin. However, deletion of the leptin gene by creation of double mutant $\left(\mathrm{A}^{\mathrm{y} / \mathrm{a}} o b / o b\right)$ mice resulted in the maintenance of leptin sensitivity, inferring that leptin resistance in $\mathrm{A} / \mathrm{a}$ mice is due to chronic desensitization to leptin signaling [28]. Moreover, Correia et al. [29] demonstrated that resistance to leptin's satiety actions does not preclude sustained leptin responsiveness of 


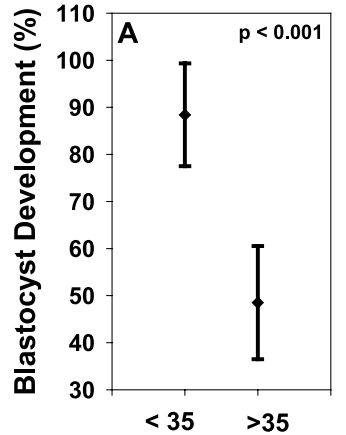

[Leptin] ng/ml
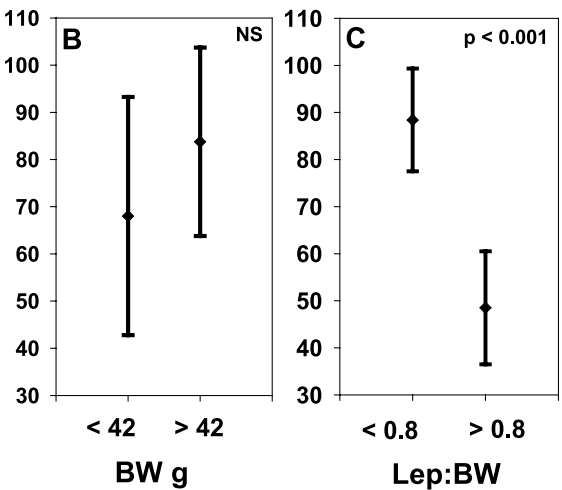

Figure 5. Relationship between blastocyst development in vitro (percent, mean \pm SD) and serum leptin concentration $(\mathbf{A})$, body weight $(\mathbf{B})$, and leptin:BW ratio $(\mathbf{C})$ in 180-d old lethal yellow mice. There was a strong negative correlation between blastocyst development and leptin and leptin:BW ratio (see text), but no correlation between blastocyst development and body weight in these animals.

sympathetic nerves, indicating that leptin sensitivity is variable among tissues and dependent upon specific signaling pathways.

To elucidate whether impaired fertility in aging $\mathrm{A}^{\mathrm{y}} / \mathrm{a}$ mice is due to intrinsic ovarian defects or to extraovarian factors, Granholm and Dickens [22] performed reciprocal ovarian transplantation between young (70$90 \mathrm{~d}$ old) $\mathrm{A}^{\mathrm{y} / \mathrm{a}}$ and $\mathrm{a} / \mathrm{a}$ mice and followed reproductive function as the animals aged. They found that BL mice with transplanted ovaries from LY mice exhibited normal fertility. In contrast, LY mice with transplanted ovaries from BL mice experienced diminished reproductive function similar to intact LY mice [22]. These authors concluded that there was no underlying intrinsic defect in the ovaries of $\mathrm{A} / / \mathrm{a}$ mice, but rather impaired fertility must result from either abnormal hypothalamic-pituitary control or extraovarian factors that altered the function of ovarian cells.

The progressive development of hypothalamic leptin resistance in LY mice was consistent with the observations of Granholm and Dickens [22] and with our present data. That a subset of aging LY mice failed to ovulate and that ovulation failure was strongly correlated with high leptin levels and leptin:BW ratios, but not directly with body weight, may be predicted, for example, if hypothalamic leptin insensitivity resulted in diminished gonadotropin secretion and/ or an attenuated LH surge.

Diminished blastocyst development of embryos from aging LY mice indicates that oocyte developmental competence was impaired, even though these mice exhibited ovulatory cycles. That impaired blastocyst development correlated strongly with serum leptin concentration and leptin:BW ratio, but not BW, is very similar to our previous results from human IVF. In both the human IVF population [14] and LY mice, leptin concentrations standardized to BMI or BW revealed a slightly stronger relationship than leptin concentration alone. It remains to be determined whether these similarities have a physiological basis. Leptin concentrations that exceed that predicted solely by body fat mass are suggestive of leptin resistance. Therefore the data imply that leptin sensitivity may be a more critical factor than leptin levels per se. Whether impaired oocyte developmental competence was the result of inadequate gonadotropin support or due to a defect in the follicular environment that may be related to altered leptin 
action in the ovary remains to be determined. That the women in our earlier IVF study were all GnRH down-regulated and stimulated with exogenous gonadotropin may suggest that the poorer embryo development was not a consequence of inadequate gonadotropin support in that particular case [14].

In conclusion, the LY mouse exhibits early reproductive senescence that is strongly correlated with increasing leptin levels and apparent development of leptin resistance. The characteristics of declining reproductive function are similar to those observed in obese infertile women. Therefore the LY mouse appears to be a valid animal model for elucidating the role of leptin in altered reproductive function associated with human obesity.

\section{ACKNOWLEDGEMENTS}

This work was supported by NIH grant R 15 HD044438 and NIH grant 2P20 RR016479 from the INBRE program of the National Center for Research Resources. The contents are solely the responsibility of the authors and do not necessarily represent the official views of NIH.

\section{REFERENCES}

[1] Caro JF, Kolaczynski J, Nyce M, Ohannesian J, Opentanova I, Goldman W, Lynn R, Zhang P, Sinha M, Considine R. Decreased cerebrospinal-fluid/serum leptin ratio in obesity: a possible mechanism for leptin resistance. Lancet 1996, 348: 159-161.

[2] Schwartz M, Peskind E, Raskind M, Boyko E, Porte D. Cerebrospinal fluid leptin levels: relationship to plasma levels and to adiposity in humans. Nat Med 1996, 2: 589-593.

[3] Steinberg GR, Dyck DJ. Development of leptin resistance in rat soleus muscle in response to high-fat diets. Am J Physiol 2000, 279: E1374-E1382.

[4] Cioffi JA, Van Blerkom J, Antczak M, Shafer A, Wittmer S, Snodgrass HR. The expression of leptin and its receptors in pre-ovulatory human follicles. Mol Hum Reprod 1997, 3: $467-472$.
[5] Karlsson C, Lindell K, Svensson E, Bergh C, Lind P, Billig H, Carlsson LM, Carlsson B. Expression of functional leptin receptors in the human ovary. J Clin Endocrinol Metab 1997, 82: 4144-4148.

[6] Ruiz-Cortez ZT, Men T, Palin MF, Downey BR, Lacroix DA, Murphy BD. Porcine leptin receptor: molecular structure and expression in the ovary. Mol Reprod Dev 2000, 56: 465474.

[7] Ryan NK, Woodhouse CM, Van Der Hoek KH, Gilchrist RB, Armstrong DT, Norman RJ. Expression of leptin and its receptor in the murine ovary: possible role in the regulation of oocyte maturation. Biol Reprod 2002, 66: 1548-1554.

[8] Matsuoka T, Tahara M, Yokoi T, Masumoto N, Takeda T, Yamaguchi M, Tasaka K, Kurachi $\mathrm{H}$, Murata Y. Tyrosine phosphorylation of STAT3 by leptin through leptin receptor in mouse metaphase 2 stage oocyte. Biochem Biophys Res Commun 1999, 256: 480-484.

[9] Kawamura K, Sato N, Fukuda J, Kodama H, Kumagai J, Tanikawa H, Nakamura A, Tanaka T. Leptin promotes the development of mouse preimplantation embryos in vitro. Endocrinology 2002, 143: 1922-1931.

[10] Chehab FF, Lim ME, Lu R. Correction of the sterility defect in homozygous obese female mice by treatment with the human recombinant leptin. Nat Genet 1996, 12: 318-320.

[11] Barash IA, Cheung CC, Weigle DS, Ren H, Kabigting EB, Kuijper JL, Clifton DK, Steiner RA. Leptin is a metabolic signal to the reproductive system. Endocrinology 1996, 137: 3144-3147.

[12] Yu WH, Kimura M, Walczewska A, Karanth S, McCann SM. Role of leptin in hypothalamic-pituitary function. Proc Natl Acad Sci USA 1997, 94: 1023-1028.

[13] Mantzoros CS, Cramer DW, Liberman RF, Barbieri RL. Predictive value of serum and follicular fluid leptin concentrations during assisted reproductive cycles in normal women and in women with the polycystic ovarian syndrome. Hum Reprod 2000, 15: 539-544.

[14] Brannian JD, Schmidt SM, Kreger DO, Hansen KA. Baseline non-fasting serum leptin concentration to body mass index ratio is predictive of IVF outcomes. Hum Reprod 2001, 16: 1819-1826.

[15] Bultman SJ, Michaud EJ, Woychik RP. Molecular characterization of the mouse agouti locus. Cell 1992, 71: 1195-1204. 
[16] Lu D, Willard D, Patel IR, Kadwell S, Overton L, Kost T, Luther M, Chen W, Woychik RP, Wilkison WO. Agouti protein is an antagonist of the melanocyte-stimulating hormone receptor. Nature 1994, 371: 799-802.

[17] Ollmann MM, Wilson BD, Yang YK, Kerns JA, Chen Y, Gantz I, Barsh GS. Antagonism of central melanocortin receptors in vitro and in vivo by agouti-related protein. Science 1997, 278: 135-138.

[18] Wolff GL, Roberts DW, Mountjoy KG. Physiological consequences of ectopic agouti gene expression: the yellow obese mouse syndrome. Physiol Genomics 1999, 1: 151-163.

[19] Klebig M, Wilkinson J, Geisler J, Woychik R. Ectopic expression of the agouti gene in transgenic mice causes obesity, features of type II diabetes, and yellow fur. Proc Natl Acad Sci USA 1995, 92: 4728-4732.

[20] Zemel M, Jones B, Moore J. Agouti regulation of leptin in adipocytes. FASEB J 1997, 11: A352.

[21] Halaas J, Boozer C, Blair-West J, Fidahusein N, Denton D, Friedman J. Physiological response to long-term peripheral and central leptin infusion in lean and obese mice. Proc Natl Acad Sci USA 1997, 94: 8878-8883.

[22] Granholm N, Dickens G. Effects of reciprocal ovary transplantation on reproductive performance of lethal yellow mice $\left(\mathrm{A}^{\mathrm{y}} / \mathrm{a}, \mathrm{C} 57 \mathrm{BL} /\right.$ 6J). J Reprod Fertil 1986, 78: 749-753.
[23] Zachow RJ, Magoffin DA. Direct intraovarian effects of leptin: impairment of the synergistic action of insulin-like growth factor-I on follicle-stimulating hormone-dependent estradiol-17 beta production by rat ovarian granulosa cells. Endocrinology 1997, 138: 847850 .

[24] Spicer LJ, Francisco CC. The adipose obese gene product, leptin: evidence of a direct inhibitory role in ovarian function. Endocrinology 1997, 138: 3374-3379.

[25] Brannian, JD, Zhao Y, McElroy M. Leptin inhibits gonadotrophin-stimulated granulosa cell progesterone production by antagonizing insulin action. Hum Reprod 1999, 14: 14451448 .

[26] Dunaif A. Insulin resistance and the polycystic ovary syndrome: mechanism and implications for pathogenesis. Endocr Rev 1997, 18: $774-800$.

[27] Wilson B, Ollmann M, Barsh G. The role of agouti-related protein in regulating body weight. Mol Med Today 1999, 5: 250-256.

[28] Boston BA, Blaydon KM, Varnerin J, Cone RD. Independent and additive effects of central POMC and leptin pathways on murine obesity. Science 1997, 278: 1641-1644.

[29] Correia M, Haynes W, Rahmouni K, Morgan D, Sivitz W, Allyn M. The concept of selective leptin resistance: evidence from agouti yellow obese mice. Diabetes 2002, 51: 439 442.

To access this journal online: www.edpsciences.org 